вірно, вищим рівнем старанності, що дозволяє їм також більш успішно вчитись. 3 іншого боку, це не виключає наявності більшого рівня когнітивної складності відмінників, що і дозволяє їм продукувати більшу кількість мотиваційних об'єктів і більш успішно вчитись. Тенденція зростання при вищій успішності кількості мотиваційних об'єктів, які локалізовані у віці від 25 і більше років може свідчити про наявність більш чітких планів цих респондентів у цьому періоді їх життя.

Ключові слова: навчальна успішність, мотивація, мотиваційна індукція, мотиваційний об'єкт, часова перспектива, взаємозв'язок.

Reviewed by Doctor of Psychology, prof. Z. Kovalchuk

Submitted on January, 20, 2017

UDC: 159.954 .2 .018

DOI: https://doi.org/10.24195/2414-4665-2017-1-10

\author{
Anastasiia Sannikova, \\ PhD (Candidate of Psychological Sciences), lecturer, \\ Department of Solo Singing, \\ Odessa National Music Academy named after A. V. Nejdanova, \\ 63, Novoselskoho Str., Odessa, Ukraine
}

\title{
SEARCHING FOR INDIVIDUAL DIFFERENCES IN EXPERIENCING PSYCHOLOGICAL BARRIERS
}

The paper aims to present the results of the study of the individual-psychological specificity of experiencing stage barriers by performers who differ in emotional disposition. The stage barrier in the paper is understood as negatively colored intellectual, somatic, emotional and behavioral reactions and experiences that manifest themselves in inhibition, stupor, restriction of choice and in the occurrence of such subjectively insurmountable obstacles that block the stage activity, impede success and can be overcome only in the process of certain kind of psychological work. Emotionality was chosen as a psychological factor that influences the structure of the stage barrier and the specifics of its manifestations. The study of a stable proneness to stage barriers was carried out with the help of the author's psychometric technique "Differential Diagnostics of the Propensity for Stage Barriers", in addition, the "Four Modalities Questionnaire of Emotionality" was used. The significant differences were found with the help of Student's t-test between the group of individuals with the domination of positive emotions of the "joy" pattern, on the one hand, and the rest of the groups with negative emotions domination - "anger", "fear", and "sadness". At the same time, the manifestations of stage barriers in the three groups of individuals with the dominance of negative emotions are considered to be very similar. Therefore, emotionality also affects the specificity of stage barriers. It can be assumed that the features of the emotions that accompany stage barriers, expression, behavior, the peculiarities of their control and regulation, the choice of ways of behavior aimed at inhibiting stage barriers (and perhaps their aggravation) also are different in persons with different emotional dispositions.

Keywords: emotionality, dispositions, joy, anger, fear, sadness, individual differences, psychological barrier, stage barrier.

\section{Introduction}

Stage excitement covers two groups of states that differ in their purposefulness and localization: the locus is "placed" either in the space of experiences of the stage character played by the performer, or in the space of his/her own experiences. It is the artist's experiences related to stage activities that are examined in this study.

In the scientific literature, these states are considered to be tension, stress, stage fever, nervous excitement, severe anxiety, etc. $[2 ; 3 ; 7 ; 8 ; 10 ; 11 ; 12]$. Stage discomfort destructively affects the characteristics of performer's stage activities, the emotional and artistic level of performance of a musical work and causes the emergence of stage barriers.

The stage barrier in the paper is understood as negative- ly colored intellectual, somatic, emotional and behavioral reactions and experiences that manifest themselves in inhibition, stupor, restriction of choice and in the occurrence of such subjectively insurmountable obstacles that block the stage activity, impede success and can be overcome only in the process of certain kind of psychological work.

The stage barrier as an objective phenomenon demonstrates the divergence of goals and results of performing activities; as a subjective phenomenon is manifested in stage experiences of a different kind; as a psychological phenomenon exists only in the stage (public) activity of the performer. It is in this that the unity in which the processes, states and properties of the personality are represented in the psyche, is manifested, stored and concretized, and in the form of which the stage barrier co- 
exists and manifests itself.

The experiencing of the stage barrier can be both a short-term mental state, and a stable personality property, each of which has its specific features. As a current mental state ("acute" situational experience), the stage barrier manifests itself in the inner reaction of the individual to external objective circumstances that are associated with stage activities. As a personality property ("chronic", extra-situational experience) it manifests itself in a stable tendency to experience a stage barrier in emotiogenic as well as emotionally neutral situations.

The scientific literature review has made it possible to explicate and describe the components of the structure of the stage barrier, revealing its psychological essence. These include psycho-physiological, emotional, cognitive, connotative (behavioral), control-regulatory, motivational-value, ergetic (energetic) components and an indicator of the general propensity to «stop reactions». Each of these indicators «marks» the stage situation in its own way. The combination of indicators - "markers", their qualitative and quantitative combination, determines the character of the experience of the stage barrier, its level, type, and variability.

The study of individual differences in the manifestations of the psychological barrier requires a choice of those personality traits that are actually the psychological determinants of the performer's stage activity.

Emotionality was chosen as a psychological factor that influences the structure of the stage barrier and the specifics of its manifestations.

The reason of this choice is the result of a long-term development of the concept of emotionality which, as a property of the personality, affects the specificity of its interaction with the surrounding reality, the attitude to the world, other people, oneself $[4 ; 5 ; 6 ; 9]$. Emotionality is traditionally regarded as one of the most important, along with mental activity, characteristics of individuality.

The structure of emotionality also involves qualitative characteristics - the modality and the sign of the dominant emotions. As the basic modalities, emotions of patterns "joy", "anger", "fear" [4;5] and "sadness" [6; 9] were considered. It should emphasized that the allocation of qualitative emotional characteristics as leading in the structure of emotionality makes it possible to explain the specifics of the subject's interaction with the surrounding reality.

In this research, in terms of stage barriers, we consider the qualitative characteristics of emotionality that contain information about the modality and the sign of emotional experience. The combination of these indicators, the dominance of one or several modalities constitute the individual psychological coordinates of the emotionality of every personality.

Thus, relying on the main achievements obtained during the development of the theory of emotionality [4, $5,6,9]$, we assume that the specificity of the artist's attitude towards the world (towards events, situations, people, audience, judges, oneself, etc) which arises in the process of his/her stage activity, is also determined by the character of the dominant qualitative characteristics of emotionality. Consequently, emotionality can act as a system-forming factor also in relation to the stage barrier as a stable personality trait.

The paper aims to present the results of the study of the individual-psychological specificity of experiencing stage barriers by performers who differ in emotional disposition.

\section{Research methods}

The study of a stable proneness to stage barriers was carried out with the help of the author's psychometric technique "Differential Diagnostics of the Propensity for Stage Barriers" [1], in addition, the "Four Modalities Questionnaire of Emotionality" was used [9].

Previously, a correlation analysis of the studied indicators had been carried out, which revealed significant negative correlations of the modality of $J$ (joy) and positive correlations of the modalities of A (anger), F (fear) and S (sadness) with the majority of indicators of stage barriers. To find individual differences in the manifestations of stage barriers in the performers who differ in emotional disposition, four groups of individuals with the dominance of one of the emotions were distinguished from the general sample ( $N=204)$ : a group of persons prone to emotions of the modality J (joy), A (anger ), F (fear) and S (sadness). The group of persons with emotional disposition $\mathrm{J}$ consisted of 24 respondents, group $\mathrm{A}-20$, group $\mathrm{F}-18$ respondents and group $\mathrm{S}-13$ respondents.

\section{Results and their discussion}

Fig. 1 shows the profiles of indicators of the stage barrier of individuals with a monomodal (dominance of one modality) emotional disposition. The value of each indicator is expressed in points and represents a deviation from the midline of the series which passes through a point of 24 points. The values above the midline indicate the positive pole of each indicator, below the midline about the negative one.

So, the representatives of the group $\mathbf{J}$ (the dominance of the modality of joy) are characterized by the absence of negative emotions associated with the performance, and even by the presence of pleasant emotional excitement, emotional lift (BEm-). These people have a positive attitude towards the situation of stage performance, have a high level of self-control on the stage (BCR-), they can control their feelings, thoughts, their behavior, expressive movements and mimicry during performances. Even if the representatives of this type of emotionality make a mistake, they can easily hide and correct it. Such people focus their attention on their tasks during the speech easily, even in front of an authoritative audience, their thoughts are focused on success, understanding and analysis of the stage situation and their activities (BCg-). At the same time, the representatives of group $\mathrm{J}$ differ from the representatives of other groups by their inner freedom from all "personal" emotions (BStp-), being able to experience emotions associated with a musical work, or the role performed. 


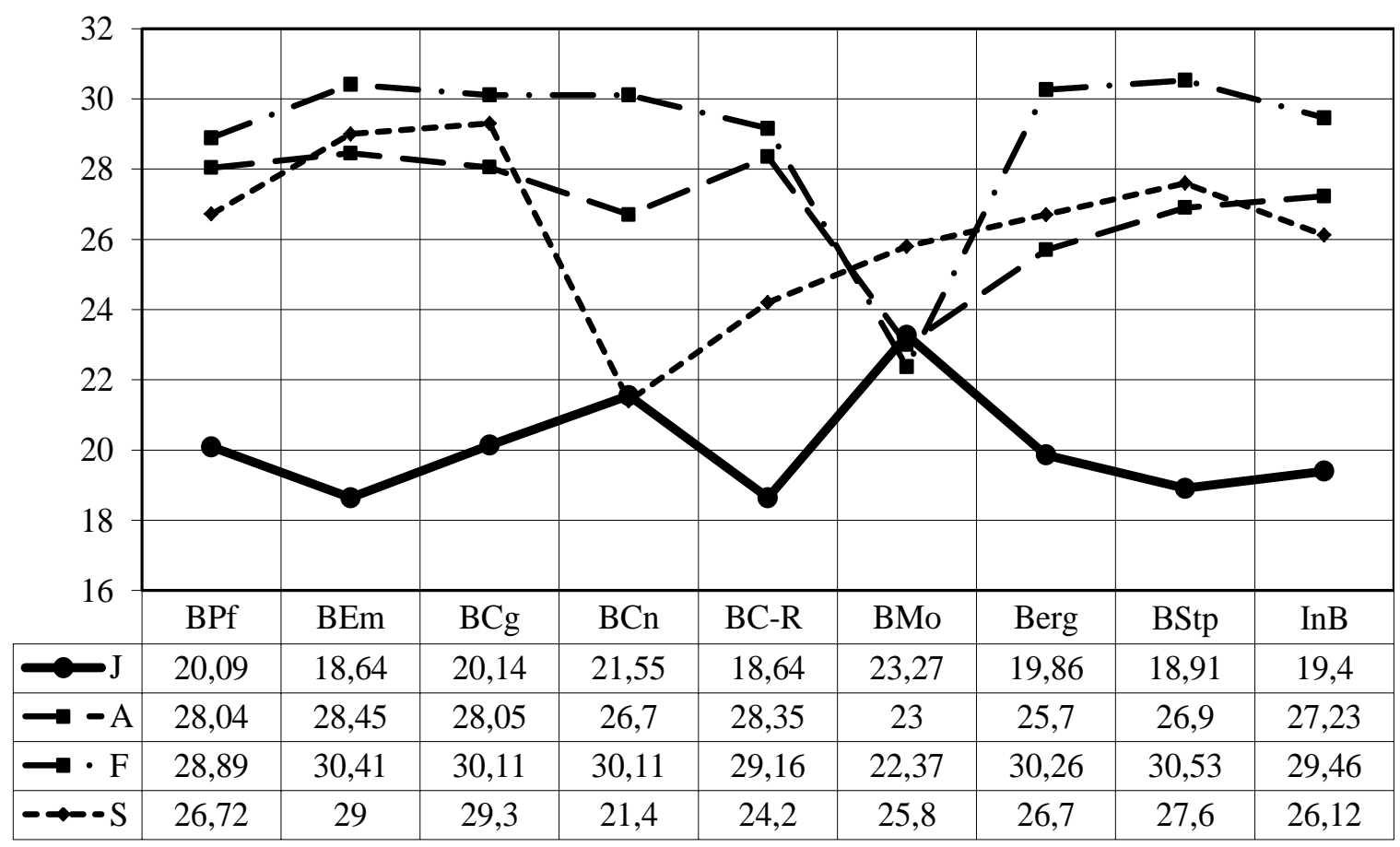

Fig. 1. Profiles of indices of stage barriers of persons with monomodal emotional disposition.

Notes: 1 ) the components of the stage barrier: BPph - psycho-physiological: BEm - emotional; $\mathrm{BCg}$ - cognitive; $\mathrm{BCn}-\mathrm{connotative} \mathrm{(behavior-}$ al); BC-R - control and regulatory; BMo - motivation; Berg - ergic; BStp - the general propensity to "stop-reactions" and InB - an index of a scenic barrier; 2) groups of persons with the dominance of a certain modality: J - joy, A - anger, F-fear, S-sadness.

The representatives of group A (dominance of the modality of anger) are characterized by the fact that before and during the performance the performer experiences strong neuropsychological tension, anxiety, excitement, strain, irritation, sometimes even rage $(\mathrm{BEm}+)$. The situation on stage is perceived by them as threatening which harms self-esteem, professional well-being. It is difficult for such performers to establish control over the situation, over themselves, over the process and the result of stage activities, it is difficult for them to control their reactions, thoughts, emotions, expression (BC-R+). Also, the representatives of this group tend to perceive the situation on stage as difficult, uncertain, unpredictable $\mathrm{BCg}+)$ which indicates the weakness of the rational component in assessing the situation, in forecasting the prospects for the development of the situation and possible consequences for the individual. And, finally, the individuals with emotional disposition of type A sometimes have sleep disorders, discomfort in the abdominal area, appetite disorders, physical weakness or tension, chills, respiratory failures, etc. (BPph+).

As for the performers belonging to the group $\mathbf{F}$ (fear), first of all, they tend to have "stop reactions" which leads to "the performance stop", "emotional plugs", fading, numbness. It is interesting that such manifestations are inherent in both the emotion of "fear" and "stop reaction". The representatives of this group perceive the stage situation as a zone of discomfort, as an event with an unfavorable result. Their intense experiences can block the performance, lead to panic attacks, or complete exhaustion, stupor (BStp+). These people experience fear of various degrees and etiologies, they are afraid of the stage, the audience, they are afraid of "burn out syndrome", failure, respectable people, the audience, the unkind reaction of the public, the constant tension of their own creative potential and so on (BEm+). Such persons spend a lot of psychological and physical energy, lose their cheerfulness, experience chronic fatigue which is caused by an exhausting struggle with their fear before the performance, lack of energy during the performance (Berg+). These performers do not fully understand what is happening to them and around them, they can not always analyze the situation, predict the prospects for the development of the situation and possible consequences for them, reveal a weak reflection (BKg+). It should be noted that the expression of such persons can be fussy (the movements of the performer are exaggeratedly expressive), or, conversely, slow. Such people cannot even begin performing, they show confusion, inadequate behavior, make mistakes, and in extreme cases they can stop the performance $(\mathrm{BCn}+)$.

The representatives of the fourth group (the individuals who are prone to emotions of the pattern $\mathbf{S}$ (sadness)) have a weak understanding of the stage situation, poor intellectual 
activity during the performance, weak anticipation and, as a consequence, an inadequate outlook for the prospects for the development of the situation and its possible consequences (BCg+). Such people experience strong neuropsychological tension, anxiety, excitement during the performance. The performance is perceived as emotionally intense which threatens their health, social and professional well-being $(\mathrm{BEm}+)$. Similarly to the group F, these people are prone to "stop reactions" which is characterized by intensively expressed experiences on the stage for any occasion, overexcitement, despair during the performance. These experiences can block their activity on the stage, lead to complete exhaustion, stupor (BStp+). These performers also experience stage barriers at the psycho-physiological level which manifests itself in different unpleasant physical sensations: hand tremor, dry mouth, palpitations, excessive sweating, fatigue or tension, respiratory disorders, etc. Some performers even fall ill before the performance (BPph+).

In order to compare these profiles, we searched for significant differences using Student's t-test between the same indicators of the stage barriers of the four groups of the respondents with the dominance of the emotions of the J, A, F and S patterns. Significant differences were found between the group of individuals with the domination of positive emotions of the "joy" pattern, on the one hand, and the rest of the groups with negative emotions domination - "anger", "fear", and "sadness". At the same time, the manifestations of stage barriers in the three groups of individuals with the dominance of negative emotions are considered to be very similar.

\section{REFERENCES}

1. A. s. (2010). Dyferentsialna diahnostyka skhylnosti do perezhyvan stsenichnykh barieriv (psykhodiahnostychnyi kompleks metodyk) [A. s. Differential diagnosis of predisposition to experiencing scenic barriers (psycho diagnostic complex of techniques)] (A. Sannikova). No. 33970; claimed 05.05.2010, reg. 05.07.2010 [in Ukrainian].

2. Vasilyuk, F. E. (1984). Psikhologiya perezhivaniya (analiz preodoleniya kriticheskikh situatsiy) [Psychology of experience (analysis of overcoming critical situations)]. Moscow: Izd-vo Mosk. un-ta [in Russian].

3. Labunskaia, V. A., Mendzheritskaia, K. A. \& Breus E. D. (2001). Psikhologiia zatrudnennogo obshcheniia: Teoriia. Metody. Diagnostika. Korrektsiia [Psychology of hindered communication: Theory. Methods. Diagnostics. Correction]. Moscow: Izdat. tsentr "Akademiia" [in Russian].

4. Nebylitsyn, V. D. (1976). Temperament [Temperament]. Psikhofiziologicheskie issledovaniia individualnykh razlichii - Psychophysiological Studies of Individual Differences (pp. 178-186). Moscow: Nauka, [in Russian].

5. Olshannikova, A. E. (1983). Emotsii $i$ vospitanie [Emotions and education]. Moscow: Znaniye [in Russian].

6. Patsiavichius, I. V. (1985). Emotsionalnost i samootsenka organizatsii deiatelnosti [Emotionality and selfassessment of the organization of activity]. Vopr. psikhol. Issues of Psychol. (Vol. 4). (pp. 134-139) [in Russian].
Therefore, emotionality also affects the specificity of stage barriers. It can be assumed that the features of the emotions that accompany stage barriers, expression, behavior, the peculiarities of their control and regulation, the choice of ways of behavior aimed at inhibiting stage barriers (and perhaps their aggravation) also are different in persons with different emotional dispositions.

\section{Conclusions}

The stage barrier is an integral psychological phenomenon, a complex of negatively colored psychophysiological, emotional, intellectual, behavioral reactions and their manifestations that contribute to the emergence of subjectively insurmountable obstacles, barriers, inhibiting, limiting, violating and blocking the performer's activity.

Emotionality as a stable individual property acts as a system-forming factor in relation to the structure of the stage barrier: the qualitative features of emotionality, namely the degree of dominance of each modality, determine the specificity of combinations of indicators of propensity to experiencing stage barriers.

This study does not solve a range of topical issues related to the problem of stage barriers. The study of the content characteristics of stage barriers, its ontogenetic aspects; conducting of cross-cultural, gender studies; perfection of methods of their psychodiagnostics and preventive maintenance; search for the ways of overcoming of stage barriers and ways of psychological correction are considered to be relevant and perspective.

7. Sannikova, A. O. (2009). Osoblyvosti perezhyvannia stsenichnykh barieriv [Features of experience of stage barriers]. Naukovyi chasopys NPU imeni M.P. Drahomanova. Seriia 12, Psykholohichni nauky - Bulletin of NPU named after M.P. Dragomanov. Series 12. Psychological Science (Vol. 26(50)), (pp. 144-147). Kyiv: NPU imeni M. P. Drahomanova [in Ukrainian].

8. Sannikova, O. P. \& Sannikova, A. O. (2014). Stsenichni bariery: dyferentsialno-psykholohichnyi pidkhid [Stage barriers: differential psychological approach]. Odesa: VMV [in Ukrainian].

9. Sannikova, O. P. (1995). Emotsionalnost v strukture lichnosti [Emotionality in the personality structure]. Odessa: Khors [in Russian].

10. Sopilko, N. V. (2008). Osoblyvosti podolannia psykholohichnykh barieriv $\mathrm{u}$ studentiv $\mathrm{v}$ protsesi navchannia [Features of overcoming psychological barriers in students during the learning process]. Extended abstract of candidate's thesis. Khmelnytskyi [in Ukrainian].

11. Rogers, C. (1947) Some observation on the organization of personality. Amer. Psychol. (Vol. 2) [in English].

12. Sannikova, A. (2016). Psychological features of individuals. International scientific professional periodical journal "The Unity of science" (Vol. 2) (pp. 70-72). Vienna, February [in English]. 


\section{ЛІТЕРАТУРА}

1. А. с. Диференціальна діагностика схильності до переживань сценічних бар'єрів (психодіагностичний комплекс методик) / А. О. Саннікова. - № 33970; заявл. 05.05.2010, реєстрац. 05.07.2010.

2. Василюк Ф.Е. Психология переживания (анализ преодоления критических ситуаций) / Ф. Е. Василюк. М. : Изд-во Моск. ун-та, 1984. - 200 с.

3. Лабунская В. А. и др. Психология затрудненного общения: Теория. Методы. Диагностика. Коррекция: Учеб. пособие для студ. высш. учеб. заведений / В. А. Лабунская, К. А. Менджерицкая, Е. Д. Бреус. М. : Издат. центр «Академия», 2001. - 288 с.

4. Небылицын В. Д. Темперамент / В. Д. Небылицын // Психофизиологические исследования индивидуальных различий. - М. : Наука, 1976. - С. $178-186$.

5. Ольшанникова А. Е. Эмоции и воспитание / А. Е. Ольшанникова. - М. : Знание, 1983. - 80 с.

6. Пацявичюс И. В. Эмоциональность и самооценка организации деятельности / И. В. Пацявичюс // Вопр. психол. - 1985. - № 4. - С. 134-139.

7. Саннікова А. О. Особливості переживання сценічних бар'єрів / А. О. Саннікова // Науковий часопис НПУ імені М.П. Драгоманова. Серія 12, Психологічні науки. - К.: НПУ імені М. П. Драгоманова, 2009. - Част. II, № 26(50). - C. 144-147.

8. Саннікова О.П. Сценічні бар'єри: диференціально-психологічний підхід: [Монографія] / О. П. Саннікова, А. О. Саннікова. - Одеса: ВМВ, 2014. -238 c.

9. Санникова О. П. Эмоциональность в структуре личности: монография / О. П. Санникова. - Одесса: Xopc, 1995. - 334 c.

10. Сопілко Н. В. Особливості подолання психологічних бар'єрів у студентів в процесі навчання: автореф. дис. ... канд. психол. наук : спец. 19.00.07 «Вікова та педагогічна психологія» / Н. В. Сопілко. - Хмельницький, 2008. - 18 с.

11. Rogers C. Some observation on the organisation of personality // Amer. Psychol. - 1947. - V. 2. - P. 3.

12. Sannikova Anastasiya. Psychological peculiarities of individuals prone to stage barriers // International scientific professional periodical journal «The Unity of science». Vienna, Austria, February, 2016, volume 2, pp. 70-72.

\section{Анастасія Олександрівна Саннікова, кандидат психологічних наук, викладач кафедри сольного співу, Одеська начіональна музична академія імені А. В. Нежданової, 63, вул. Новосельського, м. Одеса, Украӥна, 65023}

\section{ПОШУК ІНДИВІДУАЛЬНИХ ВІДМІННОСТЕЙ У ПЕРЕЖИВАННЯХ ПСИХОЛОГІЧНОГО БАР'ЄРУ}

У статті розглядаються результати дослідження індивідуально-типологічних особливостей сценічних бар'єрів як одного з видів психологічних хвилювань у творчій діяльності виконавців (співаків, музикантів, акторів тощо). Установлено, що сценічний бар'єр - це цілісний складний психологічний феномен, комплекс негативно забарвлених емоційних, інтелектуальних, поведінкових реакцій та їх проявів, які сприяють виникненню суб'єктивно непереборних перешкод, які порушують, блокують активність особистості виконавця, котра спрямована на реалізацію успішної сценічної діяльності. Експліковано й описано компоненти структури сценічного бар'єру, що розкривають його психологічну сутність: психофізіологічний, емоційний, когнітивний, конативний (поведінковий), контрольно-регулятивний, мотиваційно-ціннісний, ергічний (енергетичний), показник загальної схильності до «стоп-реакцій». Кожний із цих ознак по-своєму «маркує» сценічну ситуацію. Комбінація показників («маркерів»), їхнє якісно-кількісне сполучення визначають характер переживання сценічного бар'єру, його рівень, тип, варіативність. Наведено результати дослідження індивідуально-психологічної специфіки переживання сценічних бар'єрів виконавцями, що різняться емоційною диспозицією (схильністю до переживань емоцій певної модальності). Установлено значимі відмінності між групою осіб з домінуванням емоцій паттерну «радість», з одного боку, та іншими групами виконавців 3 домінуванням емоцій «гнів», «страх» і «печаль». У той же час яскраво презентовано подібність у змісті проявів сценічних бар'єрів у трьох груп осіб з домінуванням емоцій з від'ємним знаком (гнів, страх і печаль). Доведено, що емоційність як стійка властивість особистості виступає в ролі системотворчого чинника щодо структури сценічного бар'єру: якісні особливості емоційності, ступінь домінування кожної модальності визначають специфіку схильності до переживання сценічного бар'єру. Передбачається, що особливості емоційної палітри, які супроводжують сценічні бар'єри, експресію, поведінку, особливості їх контролю й регуляції, вибір способів поведінки, спрямованих на гальмування сценічних бар'єрів (а, можливо, і на їхнє загострення) також відрізняються в осіб з різною емоційною диспозицією.

Ключові слова: емоційність, диспозиції, радість, гнів, страх, печаль, індивідуальні відмінності, психологічний бар'єр, сценічний бар'єр.

Reviewed by Doctor of Psychology, prof. L. Zhuravlova

Submitted on January, 20, 2017 